\title{
Çölyak Hastalığında Geçici Sensorinöral Işitme Kaybı: Rastlantısal Bir Bulgu Mu?
}

\section{Reversible Sensorineural Hearing Loss in Celiac Disease: Is it A Coincidental Finding?}

\author{
Kenan Çelik, Abdullah Sakin*, Savaş Öztürk**, Mehmet Yılmaz ${ }^{* *}$, Namık Yiğit****, \\ Hikmet Feyizoğlu****, Mihriban Gürbüzel ${ }^{* \star * * *}$ \\ Ordu Akkuş Devlet Hastanesi, Dahiliye Kliniği, Ordu, Türkiye \\ *Kanuni Sultan Süleyman Eğitim ve Araştırma Hastanesi, Dahiliye Kliniği, İstanbul, Türkiye \\ **Haseki Eğitim ve Araştırma Hastanesi, Nefroloji Kliniği, İstanbul, Türkiye \\ ***istanbul Üniversitesi Cerrahpaşa Tıp Fakültesi, Kulak Burun Boğaz Anabilim Dalı, Istanbul, Türkiye \\ $* * *$ Haseki Eğitim ve Araştırma Hastanesi, Dahiliye Kliniği, Istanbul, Türkiye \\ $* * * *$ Haseki Eğitim ve Araştırma Hastanesi, Patoloji Kliniği, istanbul, Türkiye
}

\section{Özet}

Çölyak hastalığı (ÇH), alınan glutene karşı immün yanıtın oluşmasıyla karakterize ince bağırsağın otoimmün bir hastalığıdır. Bu yanıt villusların karakteristik zarar görmesine neden olup sonuçta malabsorbsiyon gelişir. ÇH'nin klinik bulgu ve belirtileri çocukluk veya yetişkin yaşamda başlayabilir. Bazı bireyler tamamen asemptomatiktir. Çölyak krizi potansiyel olarak ölümcül olabilen şiddetli ve akut başlangıçı ÇH olanlar için kullanılan bir terimdir. Her ne kadar ÇH'de çeşitli intestinal dışı belirti ve bulgular olsa da, işitme ile ilgili çelişkili bildirimler de bulunmaktadır. Bu olguda malabsorbsiyon nedeniyle tetkik edilirken beraberinde hafif-orta düzeyde geçici ani sensorinöral işitme kaybı (SNIK) da saptanan çölyak hastası sunulmuştur. (Haseki Tıp Bülteni 2013; 51: 190-2)

Anahtar Kelimeler: Çölyak hastalığı; işitme kaybı,sensörinöral

\section{Giriş}

Çölyak hastalığı $(C ̧ H)$, çeşitli gıdalarla alınan glutene karşı immün yanıtın gelişmesi sonucu ortaya çıkan ince bağırsağın otoimmün bir hastalığıdır. Bu yanıt karakteristik villus hasarına neden olup malabsorbsiyona yol açar (1). Çölyak

\begin{abstract}
Celiac Disease $(C D)$ is an autoimmune disease of the small intestine characterized by the immune response against ingested gluten. This response causes characteristic damage to the villi, which in turn results in malabsorption. Clinical signs and symptoms of CD may start early in childhood or in adulthood. Some people are completely asymptomatic. The term celiac crisis is used for patients with acuteonset severe abdominal pain which is potentially fatal. Although various extraintestinal signs and symptoms have been defined in $C D$, there are contradictory reports regarding hearing loss. We hereby report a patient with celiac disease who was investigated for malabsorption and was diagnosed with mild to medium temporary sudden sensorineural hearing loss (SNHL). (The Medical Bulletin of Haseki 2013; 51: 190-2)
\end{abstract}

Key Words: Celiac Disease; Hearing Loss, Sensorineural

krizi ise, ölümcül olabilen şiddetli ve akut başlangıçlı ÇH olanlar için kullanılan bir terimdir. Klinik olarak, şiddetli ishal, dehidratasyon ve hipokalemi, hipomagnezemi, hipokalsemi, hipoproteinemi gibi metabolik bozukluklar ile karakterizedir. Intestinal dışı organ tutulumu olabildiği bildirilse de işitme 
kaybı ile ilişkili çelişkili çalışmalar sunulmuştur. Ani işitme kaybı üç günden kısa sürede ortaya çıkan, odyolojik değerlendirmede birbirini takip eden 3 frekansta 30 dB'den fazla sensorinöral tip işitme kaybının olduğu klinik tablodur. Travma, enfeksiyonlar, intrakraniyal kitleler, multipl skleroz, otoimmün-metabolik hastalıklar ani işitme kaybına neden olabilmektedir. Burada malabsorbsiyon nedeniyle tetkik edilirken hafif-orta düzeyde ani sensorinöral işitme kaybı (SNIK) saptanan ve ÇH tanısı konan bir vaka sunulmuştur.

\section{Olgu Sunumu}

Yirmi üç yaşında kadın hasta bulantı, kusma, ishal, yürüyememe ve işitme kaybı şikayetleri ile polikliniğimize başvurdu. Tarafımıza başvurmadan yirmi gün önce düşük nedeniyle küretaj uygulanma öyküsü olan hastanın şikayetleri bu tarihten itibaren başlamış. Dış merkezde yapılan tetkiklerinde $\mathrm{Na}: 133 \mathrm{mmol} / \mathrm{L}$ (136-146), K: 1.8 $\mathrm{mmol} / \mathrm{L}$ (3.5-5.1), Cl: $104 \mathrm{mmol} / \mathrm{L}$ (98-106), kreatinin: 1.21 mg/dl (0.84-1.25), kalsiyum: 6.3 mg/dl (8.8-10.6) saptanan hastaya ayaktan medikal tedavi verilmiş. Mevcut olan bulantı, kusma, ishal şikayetlerine yürüyememe ve işitme kaybı eklenmesi üzerine hasta tarafımıza başvurdu. Hasta ileri tetkik ve tedavi amacıyla kliniğimize yatıııdı. Tetkiklerinde $\mathrm{Na}: 131 \mathrm{mmol} / \mathrm{l}$ (136-146), K: $2 \mathrm{mmol} / \mathrm{l}$ (3.5-5.1), Cl: 94 mmol/I (98-106), INR: 1,65 (0.8-1.2), total protein: $4.3 \mathrm{~g} / \mathrm{l}$ (6.6-8.3), albümin: $2.3 \mathrm{~g} / \mathrm{l}(3.5-5.2)$, Ca: $5.7 \mathrm{mg} / \mathrm{dl}(8.8-$ 10.6), P: $2,5 \mathrm{mg} / \mathrm{dl}$ (2.5-4.5), Mg: $0.9 \mathrm{mg} / \mathrm{dl}$ (1.8-2.6) saptandı (Tablo 1). Hipokalemi, hipokalsemi, hipoproteinemi ve hipomagnezemisi olan hastanın PTH: 201 pg/ml (12-65), 25-OH vitamin D seviyesi: $4.55 \mathrm{nmol} / \mathrm{l}(10-40)$ ve arter kan gazında pH: 7.51 (7.35-7.45), HCO3: 27 (22-26), PCO2: 31 (35-45), anyon açığı $12 \mathrm{mEq} / \mathrm{lt}$ idi. 24 saatlik idrarda elektrolit kaybı saptanmadı ve renin düzeyinde hafif artış saptanırken aldosteron düzeyi normaldi (Tablo 1). Hastanın ishaline yönelik yapılan gaita mikroskobisi, gaita kültürü ve gaitada

\begin{tabular}{|l|l|}
\hline \multicolumn{2}{|l|}{ Tablo 1. Hastanın laboratuvar verileri } \\
\hline Sodyum $(\mathrm{mmol} / \mathrm{l})$ & $131(136-146)$ \\
\hline Potasyum $(\mathrm{mmol} / \mathrm{l})$ & $2(3.5-5.1)$ \\
\hline Klor $(\mathrm{mmol} / \mathrm{l})$ & $94(98-106)$ \\
\hline INR & $1.65(0.8-1.2)$ \\
\hline Total protein (gr/l) & $4.3(6.6-8.3)$ \\
\hline Albumin $(\mathrm{gr} / \mathrm{l})$ & $2.3(3.5-5.2)$ \\
\hline Ca $(\mathrm{mg} / \mathrm{dl})$ & $5.7(8.8-10.6)$ \\
\hline $\mathrm{P}(\mathrm{mg} / \mathrm{dl})$ & $2.5(2.5-4.5)$ \\
\hline $\mathrm{Mg}(\mathrm{mg} / \mathrm{dl})$ & $0.9(1.8-2.6)$ \\
\hline Renin $(\mathrm{ng} / \mathrm{ml})$ & $11.5(0.2-3.4)$ \\
\hline Aldosteron $(\mathrm{pg} / \mathrm{ml})$ & $74(50-300)$ \\
\hline PTH $(\mathrm{pg} / \mathrm{ml})$ & $201(12-65)$ \\
\hline $25-O H \mathrm{Vitamin} \mathrm{D}(\mathrm{nmol} / \mathrm{l})$ & $4.55(10-40)$ \\
\hline
\end{tabular}

sindirim testlerinde özellik yoktu. Ön planda malabsorbsiyon düşünülen, olası tubulopatiler açısından nefroloji bölümüne danışılan hastanın elektrolit imbalansı ve işitme kaybı olması nedeniyle Bartter sendromu ön tanısı ile takip edilmesi ancak hastanın tekrarlayan ishal şikayetinin malabsorbsiyon sendromu ile uyumlu olduğu ve işitme kaybı açısından Kulak Burun Boğaz (KBB) Hastalıkları Kliniği ile konsültasyonu önerildi. Bu arada hastanın malabsorbsiyona yönelik yapılan üst gastrointestinal endoskopisinde gastrodouodenit saptanıp duodenum 2. kıtadan alınan biyopsisinde kronik nonspesifik duodenit, fokal villöz yassılaşma ve intraepitelyal lenfosit artışı saptandı (Şekil 1 ve 2). Bu patolojik bulgular Marsh-II sınıflandırmasına uymaktaydı. Otoantikorlarından antigliadin IgA: $160 \mathrm{EU} / \mathrm{ml}$ (0-25), antigliadin IgM: $45 \mathrm{EU} / \mathrm{ml}$ (0-25), antiendomizyum IgA: $300 \mathrm{mg} / \mathrm{dl}$ (10-60) saptandı. Klinik, endoskopik ve laboratuvar bulguları ile hastada çölyak hastalığı ve krizi düşünüldü. Çölyak klinik bulguları

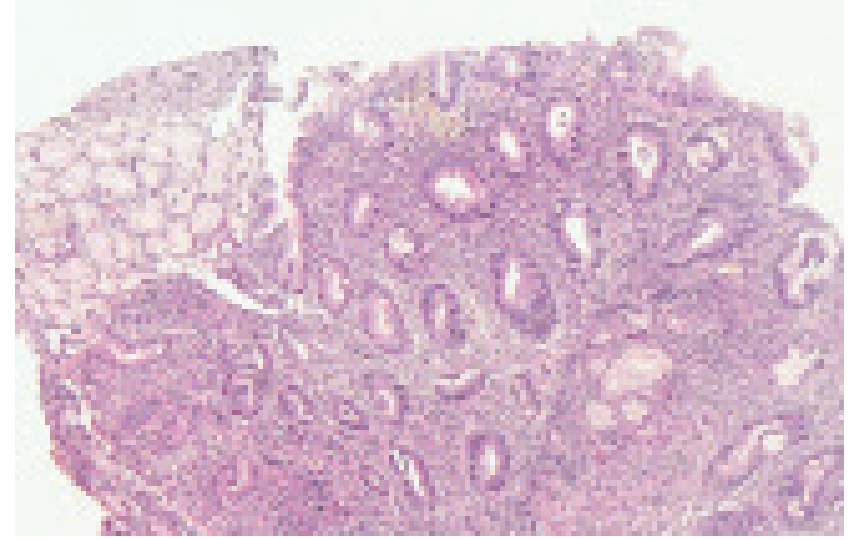

Şekil 1. Villuslarda düzleşme ve atrofi, kriptlerde hiperplazi, intraepitelyal lenfosit artışı saptandı. (H+E X100)

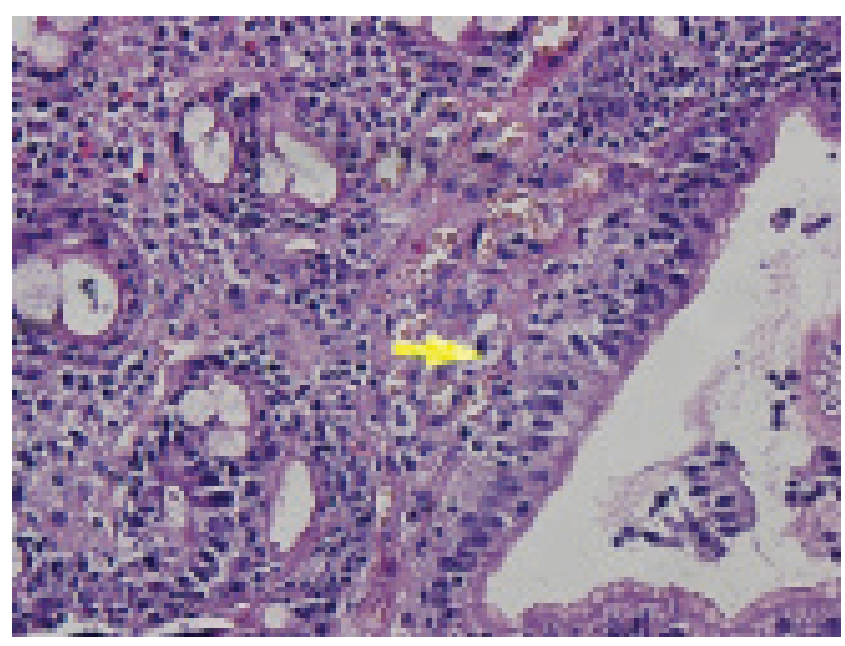

Şekil 2. Intraepitelyal lenfositlerde belirgin artış saptandı. (H+E X400) 
ile beraber işitme kaybı olan hasta KBB bölümüne danışıld;; hastanın odyolojik değerlendirmesinde sağ ve sol kulakta 45 dB sensorinöral tip işitme kaybı saptandı. Hastanın elektrolit imbalansı düzeltidikten sonra tekrar değerlendirilmesi önerildi. Elektrolit imbalansı düzeltilip çölyak hastalığına yönelik diyet uygulandıktan sonra hastanın işitmesi üçer gün aralıkla odyolojik olarak takip edildi. 15. günde yapılan işitme değerlendirmesinde hastanın saf ses ortalamasının normal seviyeye ( $20 \mathrm{~dB}$ altı) ulaştığı görüldü. Çölyak diyeti ile taburcu edilen hasta gastroenteroloji polikliniğimizden medikal tedavi almadan sorunsuz bir şekilde takip edilmektedir.

\section{Tartışma}

Çölyak hastalığı (ÇH), gıdalarla alınan glutene karşı bağışıklık yanıt gelişmesi nedeniyle ortaya çıkan bağırsağın otoimmün bir hastalığıdır. Bu yanıt villusların karakteristik zarar görmesine neden olup malabsorbsiyona neden olur (1). ÇH'nin klinik bulgu ve belirtileri çocukluk veya yetişkin yaşamda başlayabilir. Bazı bireyler tamamen semptomsuzdur (2). Yeni yürümeye başlayan çocuklar ve küçük çocuklar kronik ishal, kusma, iştahsızlık, karın şişliği, karın ağrısı, sinirlilik, bazen de diyete gluten girmesinden sonra gelişme geriliği ile ortaya çıkarlar (3). Kimi zaman ise gastrointestinal semptomlar olmadan (örneğin; boy kısalığı ile) veya semptomsuz olabilirler. ÇH tanısı serolojik testler ve bağırsak biyopsisinde karakteristik histopatolojik bulgularla konulmaktadır (4). Çölyak hastalığının tanısında ince bağırsak mukoza biyopsisi altın standart olmaya devam etmektedir. Tanı ve izlemde kullanılabilecek yeni serolojik belirteçler son yıllarda dikkati çekmektedir. Yüksek düzeyde doku transglutaminaz antikor (TTG) pozitifliğinin duodenum biyopsisini gereksiz kılacağı ileri sürülmeye başlanmışıır (5). ÇH histolojik özellikleri; kript hiperplazisi ve intraepitelyal lenfosit artışı, villöz atrofi ile karakterizedir. Marsh tarafından önerilen kriterler (0-4) genellikle bu özellikler açısından, hastalığın derecelendirilmesinde kullanılır (6). Çölyak krizi potansiyel olarak ölümcül olabilen şiddetli ve akut başlangıçı ÇH olanlar için kullanılan bir terimdir. Klinik olarak şiddetli ishal, dehidratasyon ve hipokalemi, hipomagnezemi, hipokalsemi, hipoproteinemi gibi metabolik bozukluklar ile karakterizedir (7). Bizim hastamızda çölyak krizi olarak değerlendirilmekle birlikte işitme kaybı mevcuttu. KBB bölümüne danışılan hastada hafif-orta düzeyde SNiK saptandı. Bizim vakamızda çölyak krizi ile başvurduğu, çeșitli elektrolit imbalanslarının da bulunduğu bir dönemde SNiK saptanmış ve hastalık kontrol altına alındıktan ve elektrolitler düzeltildikten sonra hastadaki işitme sorunu gerilemiştir. Bu durumda SNiK'den çölyak krizinin mi yoksa elektrolit imbalansının mı sorumlu olduğunu kesin olarak ortaya koymak mümkün değildir. Literatürde $\mathrm{ÇH}^{\prime}$ de SNiK ile ilgili yapılan çalışmalarda net bir sonuç ortaya konmamıştır. Literatürde pediatrik 25 çölyak hastası ve 25 sağlıklı kontrol grubu ile ÇH ve SNiK insidansını saptamak amacıyla yapılan bir çalışmada odyometrik istatistiksel analizlerde anlamlı farklıık saptanmışıı (8). Bir diğer 32 pediatrik ÇH ve 32 kontrol grubuyla farklı frekanslarda SNIK sıklığını ve şiddetini belirlemek amacıyla yapılan çalışmada ÇH ve SNiK arasında bir ilişki olduğunu düşündüren, sağlıklı kontrollere göre pediatrik çölyak hastalarında SNiK sıklığı yüksek saptanmıştır. Bu çalışmanın bulguları yeni tanı almış pediatrik ÇH hastalarda işitme kaybının aranması gerektiğini göstermektedir (9). Çölyak hastalığının otoantikorlarla ve otoimmün bozukluklarla ilişkisini saptamak amacıyla 59 ÇH hastası ve 59 kontrol grubu arasında yapılan bir diğer çalışmada hem odyometrik analiz hemde organ spesifik olmayan ve nörolojik otoantikorlarla ilişkisi araştırımıştır. Beş ÇH ve 2 kontrol grubunda SNiK saptanıp çalışmada SNiK açısından istatistiksel anlamlı farklılık saptanmamışıı. 5 SNiK'li çölyak hastasının ikisinde ve SNiK olmayan 54 hastanın 12'sinde otoantikor testlerinden en az biri pozitif saptanmıştır. Antinöronal antikorlar SNiK'li 5 çölyak hastada negatif saptanmış. Bu 5 hastanın birinde Hashimoto tiroiditi tespit edilmiş ve SNiK'in çölyak hastalarında raslantısal olarak ortaya çıktığı sonucuna varılmışır (10).

Sonuç olarak; ÇH vakalarında her ne kadar rastlantısal olarak SNiK ortaya çıkabilse de hastalığın kendisine veya ortaya çıkarttığı sıvı elektrolit imbalansı ile ilişkili olabilecek geçici işitme kayıplarının olabileceği akılda tutulmalı ve altta yatan hastalığın düzeltilmesi sonrası işitmenin tekrar değerlendirilmesi gerekir.

\section{Kaynaklar}

1. Farrell RJ, Kelly C. Celiac sprue. N Engl J Med 2002;346:180-8.

2. Tully MA. Pediatric celiac disease. Gastroenterol Nurs 2008;31:132-40.

3. Steens RF, Csizmadia CG, George EK, Ninaber MK, Hira Sing RA, Mearin ML. A national prospective study on childhood celiac disease in the Netherlands 1993;2000 an increasing recognition and a changing clinical picture. J Pediatr 2005;147:239-43.

4. Hill ID, Dirks MH, Liptak GS, et al. Guideline for the diagnosis and treatment of celiac disease in children: recommendations of the North American Society for Pediatric Gastroenterology, Hepatology and Nutrition. J Pediatr Gastroenterol Nutr 2005;40:1-19

5. Reha Artan. Çölyak Hastalığında Gelişmeler. Türkiye Klinikleri J Pediatr Sci 2012;8:48-55.

6. Marsh MN. Gluten, major histocompatibility complex, and the small intestine. A molecular and immunobiologic approach to the spectrum of gluten sensitivity ('celiac sprue'). Gastroenterology 1992;102:330-54.

7. Walia A, Thapa BR. Celiac crisis. Indian Pediatr 2005;42:1169.

8. Solmaz F, Unal F, Apuhan T. Celiac disease and sensorineural hearing loss in children. Acta Otolaryngol 2012;132:146-51.

9. Hizli S, Karabulut H, Ozdemir O, et al. Sensorineural hearing loss in pediatric celiac patients. Int J Pediatr Otorhinolaryngol 2011;75:65-8

10. Volta $U$,Ferri GG, De Giorgio $R$, et al. Sensorineural hearing loss and celiac disease: a coincidental finding.Can J Gastroenterol 2009;23:531-5. 